\title{
Policy Implications for Reforming Public Employment Center: How Can Service Performance Be Improved?
}

\author{
Young-Min Lee ${ }^{1}$ and Ji-Hyun $\mathrm{Oh}^{2 *}$ \\ ${ }^{1}$ Graduate school of Human Resources Development for Women, \\ Sookmyung Women's University \\ $10047^{\text {th }}$ street, Chungparo, Yongsan-gu, Seoul 140-742, Korea \\ ${ }^{2}$ Graduate Program of Human Resource Development Policy, \\ Sookmyung Women's University \\ $10047^{\text {th }}$ street, Chungparo, Yongsan-gu, Seoul 140-742, Korea \\ ${ }^{1}$ ymlee@sookmyung.ac.kr, ${ }^{2}$ successjh05@naver.com
}

\begin{abstract}
This study will investigate the development directions and tasks of employment centers based on the problems and causes that have been identified previous studies and give policy insights that will help to accelerate employment among job hunters including the most vulnerable groups, such as young people, women, the aged, and the disabled. This study roughly suggests improving four elements in order to expand employment service functions both public and private and to stimulate the execution of effective government policies. First, it is necessary to expand private employment services and introduce competition to improve the quality of employment services. Second, it is necessary to connect employment and welfare and provide one-stop service. Third, the government must allocate budgets for long-term employment services to face the global economic crises. Fourth, it is necessary to develop a channel that supplies the right workers to medium and small-sized enterprises at the right time, and also global capabilities should be reinforced to respond to the transfer of global manpower, finding and supplying capable persons at both the local and national levels. Additionally, establishing public temporary agencies must first be considered for social services.
\end{abstract}

Keywords: Employment, Employment Center, Public Employment Service, Private Employment Service, and Development Scheme of Employment Service

\section{Introduction}

After the financial crisis in 1997 and the international financial crisis in 2008, with the massive unemployment from the slow worldwide economic growth and the disappearance of lifelong employment [1, 2], Korea has also focused on its employment infrastructure to resolve its unemployment issues. Because of the skyrocketing unemployment rate, the government began to put full-scale efforts into its employment service, such as enhancing customer access, providing one-stop services and customer-specialized service and so forth. However, developing an employment services infrastructure is a long-term consideration that requires substantial time, and meanwhile, the qualitative improvement of employment services in both the public and private sectors has advanced rather slowly [3-5].

In 1998, the public sector integrated the employment affairs of local labor offices and employment insurance works into the employment centers. After 2000, when the group counseling program for employment support was developed, facilitating employment

* Corresponding Author 
services in the private sector and strengthening employment services in the public sector have been the means of advancing national employment support services, and employment service policies have become one of the critical fields of full-scale labor policy [6].

Notwithstanding such a short history, various employment service techniques and programs based in the promptness and learning culture that is unique to Korea have been introduced and implemented. However, by operating similar public employee service delivery systems for each department, for each local government, and for each business, the status and role of the employment centers have become vulnerable, and there have been repeated budget investments, partially excessive service and some works that have failed to provide adequate public employee service [7].

Meanwhile, private institutions have expanded to offer indispensable supplements to the public-sector options in order to provide diversified employment services to meet the demand. Accordingly, the government is fully devoted to supplementing the private employee services by optimizing the occupational stabilization functions and facilitation of human resource supply through the 2006 employment service advancement plan [8]. Therefore, the private employee service institutions have increased in size around certain institutions, with a trend of expanding their service territories into entire HR areas. In contrast, the employment centers have numerous problems with lack of employee specialization, frequent work transfers, low service quality caused by excessive administrative tasks, increased term-based employees in the employment centers, and declining skill levels.

Furthermore, because the legal and systematic basis for strengthening the status and role of the employment centers is vulnerable and a government strategy for developing employment services has yet to be established, there is a limit to how much the efficiency of employment services can be optimized. There is no detailed model for connection, adjustment and partnership between regional employment centers and labor agencies and employment centers; private employee service institutions and employment centers; local governments and employment centers; and government institutions and employment centers, and the employment centers only focus on administrative execution because of the business-oriented outcome evaluations [7].

Although numerous issues have been highlighted, studies on facilitating the employment centers are still lacking. Therefore, the purpose of this paper is to study the employment centers' development schemes and tasks based on the issues that were presented and to investigate the policy implications for the centers.

\section{Method}

This study aims to investigate the employment centers' development schemes and tasks based on the issues, specifically the policy implications as highlighted in numerous documents, and also to present certain implications. In order to accomplish the purpose of this study, theses, studies, newspaper articles, and government data from 2010 to 2015 were researched.

Studies were researched on online sites such as the Korean Education and Research Information Service (KERIS) database and RISS, as well as the well-known academic DB and the Ministry of Employment and Labor, which has processed numerous studies in relation to this study's research themes, the Korea Employment Information Service, the Korea Labor Institute, the Employment Information Center, the Korea Law Information Center, Google Site, etc.

The key words for the study were 'employment,' 'employment center,' 'public employment service,' 'private employment service,' and 'employment center development scheme'. As a result of above-mentioned process, a total of 30 theses and 10 relevant articles were accepted for final use. Because Torraco observed that to synthesize the 
literature is to review a body of research and focus on key issues, the core findings from the various literature reviews were synthesized and reported on to accomplish this study's purpose [9].

\section{Literature Review}

\subsection{Legal Systems for Employment Services}

Generally, national public employment services are emphasized as serving to adjust job hunters' standards through career counseling, vocational guidance, and providing employment information, solving the problem of information asymmetry, and providing appropriate employment services. These efforts could help to improve career matching, resolve insufficient manpower challenges in medium and small-sized enterprises, reduce the length of unemployment duration, and help people move to better labor markets.

Today, our legal systems for employment services rely on the Framework Act on Employment Policy, the Occupation Stabilization Law, the Employment Insurance Act, the Fair Employment Procedure Act, the Social Enterprise Promotion Act, the Act on Employment, etc., of Construction Workers, the Special Act on the Promotion of Youth Employment, the Act on Foreign Workers, the Act on Trade Adjustment Assistance Following the Free Trade Agreements, the details of all of which are shown in Table 1 [7, $10,11]$.

Table 1. Legal Systems for Employment Services

\begin{tabular}{|c|c|c|}
\hline Classification & Main contents & Remark \\
\hline $\begin{array}{c}\text { Framework Act } \\
\text { on Employment } \\
\text { Policy }\end{array}$ & $\begin{array}{l}\text { The purpose of this Act is to allow each citizen to } \\
\text { develop vocational skills throughout their lives and } \\
\text { to have more employment opportunities because of } \\
\text { the State's establishing and implementing } \\
\text { employment policies and contributing to social } \\
\text { integration by improving people's quality of life and } \\
\text { sustainable economic growth and employment by } \\
\text { supporting employment security, creating jobs, } \\
\text { securing human resources, promoting labor market } \\
\text { efficiency, and balancing between labor supply and } \\
\text { demand. } \\
\text { Regulations on providing career counseling for } \\
\text { students, offering employment assistance to } \\
\text { vulnerable groups such as youth, women, and the } \\
\text { aged, and enforcing general employment policies } \\
\text { such as establishing the Korea Employment } \\
\text { Information Service, including Korea Job World. }\end{array}$ & $\begin{array}{c}\text { Enacted on Dec. } \\
27,1993\end{array}$ \\
\hline $\begin{array}{l}\text { Employment } \\
\text { Security Act }\end{array}$ & $\begin{array}{l}\text { The purpose of this Act is to strive for employment } \\
\text { security for every worker and to contribute to the } \\
\text { balanced development of the national economy by } \\
\text { giving employees the opportunity to find work in } \\
\text { which they can develop and display their own } \\
\text { abilities and facilitating a supply and demand in the } \\
\text { workforce required for each industry through } \\
\text { cooperation between the government and the private } \\
\text { sector. } \\
\text { Regulations on employment services in a narrow }\end{array}$ & $\begin{array}{c}\text { Enacted on Dec. 6, } \\
1961\end{array}$ \\
\hline
\end{tabular}




\begin{tabular}{|c|c|c|}
\hline & $\begin{array}{l}\text { sense, such as employment assistance including job } \\
\text { placement, vocational guidance, recommendations } \\
\text { to training institutes, providing labor market } \\
\text { information, certifying employees with good work } \\
\text { histories, etc. }\end{array}$ & \\
\hline $\begin{array}{l}\text { Employment } \\
\text { Insurance Act }\end{array}$ & $\begin{array}{l}\text { The purpose of this Act is, by enforcing employment } \\
\text { insurance, to prevent unemployment, promote } \\
\text { employment, develop and improve workers' } \\
\text { vocational skills, strengthen the nation's vocational } \\
\text { guidance and job placement capacity, and stabilize } \\
\text { workers' livelihoods and promote their job-seeking } \\
\text { activities by granting necessary benefits when they } \\
\text { are out of work, thereby contributing to the nation's } \\
\text { economic and social development. } \\
\text { Regulations on employment assistance services } \\
\text { related to employment insurance, vocational skills } \\
\text { development, etc., excepting unemployment } \\
\text { benefits. }\end{array}$ & $\begin{array}{c}\text { Enacted on Dec. } \\
22,1994\end{array}$ \\
\hline $\begin{array}{c}\text { Fair Hiring } \\
\text { Procedure Act }\end{array}$ & $\begin{array}{l}\text { The purpose of this Act is to reduce burdens on job } \\
\text { seekers and protect their rights and interests by } \\
\text { prescribing minimum levels of fairness in hiring } \\
\text { procedures, such as returning hiring documents } \\
\text { submitted by job seekers in the hiring process. }\end{array}$ & $\begin{array}{c}\text { Enacted on Jan. 21, } \\
2014\end{array}$ \\
\hline $\begin{array}{c}\text { Social Enterprise } \\
\text { Promotion Act }\end{array}$ & $\begin{array}{l}\text { The purpose of this Act is to contribute to social } \\
\text { unity and to enhancing quality of life in the country } \\
\text { by expanding social services that are not sufficiently } \\
\text { supplied in our society and by creating new jobs } \\
\text { through supporting the establishment and operation } \\
\text { of social enterprises and promoting social } \\
\text { enterprises. }\end{array}$ & $\begin{array}{l}\text { Enacted on Jan. 3, } \\
2007\end{array}$ \\
\hline $\begin{array}{l}\text { Act on the } \\
\text { Employment } \\
\text { Improvement, } \\
\text { etc., of } \\
\text { Construction } \\
\text { Workers }\end{array}$ & $\begin{array}{l}\text { The purpose of this Act is to improve employment } \\
\text { and enhance the welfare of construction workers and } \\
\text { to contribute to developing the construction industry } \\
\text { by supporting and promoting construction workers' } \\
\text { employment stability and developing and elevating } \\
\text { their vocational abilities, and by offering welfare } \\
\text { such as paying mutual-aid money to retired } \\
\text { construction workers. }\end{array}$ & $\begin{array}{c}\text { Enacted on Dec. } \\
31,1996\end{array}$ \\
\hline $\begin{array}{l}\text { Special Act on } \\
\text { the Promotion of } \\
\text { Youth } \\
\text { Employment }\end{array}$ & $\begin{array}{l}\text { The purpose of this Act is to support unemployed } \\
\text { youth with workplace skill development training, } \\
\text { etc., within and outside of the country, thereby } \\
\text { promoting youth employment and contributing to } \\
\text { continued economic growth and social stability. }\end{array}$ & $\begin{array}{l}\text { Special Act on the } \\
\text { Resolution of Youth } \\
\text { Unemployment } \\
\text { (Enacted on March } \\
5,2004 \text { ) } \\
\rightarrow \text { Special Act on } \\
\text { the Promotion of } \\
\text { Youth Employment } \\
\text { (Other act revised, } \\
\text { on Oct. 9, 2009) }\end{array}$ \\
\hline $\begin{array}{l}\text { Act on Foreign } \\
\text { Workers' } \\
\text { Employment, } \\
\text { etc. } \\
\end{array}$ & $\begin{array}{l}\text { The purpose of this Act is to promote the smooth } \\
\text { supply and demand of manpower and the balanced } \\
\text { development of the national economy by } \\
\text { systematically introducing and managing foreign }\end{array}$ & $\begin{array}{c}\text { Enacted on Aug. } \\
16,2003\end{array}$ \\
\hline
\end{tabular}




\begin{tabular}{|c|c|c|}
\hline & $\begin{array}{l}\text { workers. } \\
\text { Provision of legal grounds to charge and use fees by } \\
\text { Korean-language proficiency test providers, along } \\
\text { with establishing their applications (New enactment } \\
\text { of Article } 7 \text {, Section } 3 \text { ). } \\
\text { Time for paying departure expiration insurance and } \\
\text { other fees is set to be within } 14 \text { days after the } \\
\text { insured departs (Article } 13 \text {, Section } 3 \text { ). } \\
\text { Provides the grounds for establishing a management } \\
\text { committee on dormant insurances, etc., along with } \\
\text { establishing applications for transferred insurances } \\
\text { (New enactment of Article 13, Section 2). }\end{array}$ & \\
\hline $\begin{array}{l}\text { Act on Trade } \\
\text { Adjustment } \\
\text { Assistance } \\
\text { following the } \\
\text { Free Trade } \\
\text { Agreements }\end{array}$ & $\begin{array}{l}\text { The purpose of this Act is to contribute to the } \\
\text { balanced growth of the national economy by } \\
\text { preparing effective measures for assisting } \\
\text { enterprises that engage in manufacturing or provide } \\
\text { services and that have sustained or will definitely } \\
\text { sustain negative impact as a consequence of the } \\
\text { implementation of the free trade agreements entered } \\
\text { into by the government and their employees. }\end{array}$ & $\begin{array}{c}\text { Act on Trade } \\
\text { Adjustment } \\
\text { Assistance For } \\
\text { Manufacturers, etc., } \\
\text { (Other act revised } \\
\text { on April 11, 2007) }\end{array}$ \\
\hline
\end{tabular}

Among the above legal systems for employment services, the Framework Act on Employment Policy, Occupation Stabilization Law, and Employment Insurance Act are closely related to the public legal systems for employment services. The Framework Act on Employment Policy set forth basic and general elements of employment policies to become the systematic foundation; the Occupation Stabilization Law defines employment services by employment centers in Korea; and the Employment Insurance Act addresses employment insurance, one of the main tasks performed by employment centers and that is addressed by both the Employment Insurance Act and the Occupation Stabilization Law [7].

\subsection{Current Situations and Main Jobs of Employment Center}

3.2.1. Current status of Employment Center: Employment centers were established as employment security centers in 1998 to assist with vocational training, job placement, and one-stop employment insurance, and they were renamed employment assistance centers with the unification of job security and employment insurance, and then renamed again to employment assistance centers in July 2006. At that time, the centers were expanded to respond to the administrative demands related to the dramatic increase in unemployment and the expansion of employment insurance applications from 1999 to 2001. The functions of the centers had been revised or consolidated for the provision of clientoriented employment services and the reinforcement of employment policies by local units from 2002 to 2005, and meanwhile, in 2006, some centers were abolished and others merged, especially in metropolitan cities, to improve the efficiency of their operations [8].

As of May, there are 86 employment centers; and their businesses by type are shown in Table 2 below. 
Table 2. The Business of Employment Centers by Type

\begin{tabular}{|c|c|l|}
\hline Types & Numbers & \multicolumn{1}{c|}{ Contents of Businesses } \\
\hline $\begin{array}{c}\text { Ordinary } \\
\text { Centers }\end{array}$ & 75 & $\begin{array}{l}\text { In addition to services for companies such as unemployment } \\
\text { benefits and employment assistance, the ordinary centers manage } \\
\text { employment security, develop vocational abilities, provide job } \\
\text { creation programs, etc. }\end{array}$ \\
\hline $\begin{array}{c}\text { Local } \\
\text { Centers }\end{array}$ & 11 & $\begin{array}{l}\text { Perform basic services such as unemployment benefits, } \\
\text { employment assistance, } \text { etc. to expand client access (1 to 3 } \\
\text { members at a time or up to 9 in a flexible way, depending on their } \\
\text { situations). }\end{array}$ \\
\hline
\end{tabular}

Source: Ministry of Employment and Labor Department of Employment Service Policy (2015) [12]

3.2.2. Manpower Structure of the Employment Centers: As shown in Table 3 below, the centers currently have 5,098 government and non-government employee members, including those have been suspended from duty, about one third of which consists of nongovernment employees.

Table 3. Current Manpower Structure of Employment Center (as of May 2014)

\begin{tabular}{|c|c|c|c|c|c|c|c|}
\hline & \multicolumn{9}{|c|}{ Government employees } & \multicolumn{3}{c|}{ Non-government employees } \\
\cline { 2 - 8 } Categories & Ordinary & Consulting & Statistics & Total & $\begin{array}{c}\text { Non- } \\
\text { regular } \\
\text { workers }\end{array}$ & $\begin{array}{c}\text { Temporary } \\
\text { workers }\end{array}$ & Total \\
\hline Capacity & 1,679 & 1,386 & 75 & 3,140 & 1,319 & 500 & 1,819 \\
\hline $\begin{array}{c}\text { Current } \\
\text { (inc. those } \\
\text { suspended } \\
\text { from duty) }\end{array}$ & 1,797 & 1,245 & 65 & 3,107 & 1,076 & 519 & 1,595 \\
$(1,994)$ & $(1,360)$ & $(71)$ & $(3,425)$ & $(1,153)$ & $(520)$ & $(1,673)$ \\
\hline
\end{tabular}

Source: Study on Employment of Non-government Workers in Employment Center and Ways of Combining Jobs [13]

3.2.3. Main Employment Center Services: The Ministry of Employment and Labor revised enforcement rules effective January 30, 2015. The main services by employment center department (team) suggested by the enforcement rules' operation regulations are shown in Table 4 below.

Table 4. Main Employment Center Services (as of January 30, 2015)

\begin{tabular}{|c|c|}
\hline Classification & Main Contents \\
\hline $\begin{array}{l}\text { Employment } \\
\text { assistance }\end{array}$ & $\begin{array}{l}\text { - Establish and execute its own employment steps } \\
\text { - Create jobs including offering them, finding them; and placing people } \\
\text { - Assist vulnerable groups such as youth, women; and the aged in finding } \\
\text { employment (excluding the employment success package program) } \\
\text { - Serve as an employment agency, arrange meetings between would-be } \\
\text { employers and employees, and operate permanent employment offices } \\
\text { - Offer vocational career guidance, group counseling, and opportunities } \\
\text { for field study in small but strong enterprises for youth } \\
\text { - Expand employment assistance for students from colleges and technical } \\
\text { high schools and receive public applications for civil entities }\end{array}$ \\
\hline
\end{tabular}




\begin{tabular}{|c|c|}
\hline & - Other duties not assigned to any other teams in the center. \\
\hline $\begin{array}{l}\text { Unemployment } \\
\text { benefit }\end{array}$ & $\begin{array}{l}\text { - Approve unemployment benefit applications } \\
\text { - Recognize unemployment and pay unemployment benefits } \\
\text { - Provide employment assistance programs or find jobs for those who } \\
\text { receive unemployment benefits }\end{array}$ \\
\hline $\begin{array}{l}\text { Employment } \\
\text { success } \\
\text { package }\end{array}$ & $\begin{array}{l}\text { - Implement the employment success package } \\
\text { - Cooperate with employment service agencies, self-support institutes; and } \\
\text { other related organizations }\end{array}$ \\
\hline $\begin{array}{l}\text { Company } \\
\text { assistance }\end{array}$ & $\begin{array}{l}\text { - Execute and manage employment promotion and security programs } \\
\text { - Create and improve __ or move to time-selection systems } \\
\text { - Operate child-care programs } \\
\text { - Cooperate with economic institutions for employment security and } \\
\text { promotion }\end{array}$ \\
\hline $\begin{array}{l}\text { Development } \\
\text { of vocational } \\
\text { abilities }\end{array}$ & $\begin{array}{l}\text { - Approve, appoint, and control job training courses and facilities } \\
\text { - Provide vocational training courses for active employees and the } \\
\text { unemployed. } \\
\text { - Consult on vocational ability development } \\
\text { - Expand on and assist with National Competency Standards and } \\
\text { cooperative education (such as cooperation between related institutions, } \\
\text { such as local cooperative education units' managing operation committees, } \\
\text { and protecting and overseeing interactions between studying workers and } \\
\text { employers) }\end{array}$ \\
\hline
\end{tabular}

Source: Revised Operation Regulations of Employment Centers and Employment Related Organizations (Ministry of Employment and Labor, January 30, 2015) [14]

\subsection{Foreign Cases of Employment Service Systems}

For overseas employment services, this study refers to the characteristics of programs in the US and Australia, which is considered to be relatively better, organized among advanced states [15].

3.3.1. Employment Service Systems in the USA: America began public employment services in earnest in 1993 with the establishment of Work Progress Administration projects throughout the country with cooperation of the federal government and state governments. It may be said that WPA's representative employment service systems are one-stop centers and the workforce investment board.

\section{Case 1. One-stop Centers}

As one of the most typical characteristics of the employment service systems in the USA, one-stop centers provide a package of employment services, including unemployment benefits, training, etc., with the continuous cooperation of both public and private organizations $[16,18]$. Current public employment service offices are the result of job security offices operated by state governments in the form of nonprofit private and public partnerships through which these private and public entities operate the centers as partners. Control of the centers is given to civil experts, and their jobs are in-sourced to professional employment service organizations. 
Typical functions performed by the one-stop centers are as follows: First, they provide client-oriented services and enact welfare reforms based on market principles that facilitate a labor-first welfare philosophy. Second, they serve as comprehensive service centers for the vulnerable unemployed. Unemployment centers offer services such as providing labor market information, offering active labor market engagement such as vocational training, paying unemployment benefits, providing job placement assistance for the unemployed regardless of age, and attempting to remove obstacles such as rehabilitating workers and assisting others in moving from welfare to work.

\section{Case 2. Workforce Investment Boards}

All state governments and provincial self-governing communities are required to establish Workforce Investment Boards (WIB) that respect the basic directions and guidelines of the federal government's policies, establishing detailed employment policies for individual states and regions and choosing how to operate local employment services. The majority of them, however, are managed by committees that aim to offer employment services that meet the demands of local companies. They tailor their policies and services by state or region.

Each WIB in each state or region is responsible for deciding the number, locations, and operation methods of their local or regional one-stop career center, appointing participating partners and formalizing memorandums of understanding with them, designating a director and programs, preventing conflicts between partners, etc., [17].

3.3.2. Employment Service Systems in Australia: Australia is said to have the most advanced employment services - along with the Netherlands-by making them privatized. At first, the services were operated by the government, and public services began with the establishment of the Commonwealth Employment Service in 1946. Unlike the one-stop services that are offered in developed countries, where a single agency provides unemployment benefits and employment services, Australia operates the Job Network and Centrelink, which are responsible for employment duties and unemployment, respectively.

\section{Case 1. Job Network}

Profit and nonprofit public employment service agencies were connected to the Job Network in 1998 so that they could provide direct employment services [19]. Although the public employment service agencies were being liquidated systematically until 2002, civil agencies introduced competition in the employment service market. Thus, as a civil employment service network, the Job Network provides job placement and job placement training, intensive assistance, short-term jobs, help with Working for the Dole, etc., [20]. It is characterized by its provision of deep employment services through various individual case management services. As of 2009, Australia had one or more employment service providers in 116 regions, a total of 141, of which $77 \%$ were nonprofit organizations such as churches and social welfare agencies and the remaining $23 \%$ were for-profit. This privatization through the Job Network has been assessed as successful in terms of employment costs. The Job Network was renamed Job Services Australia to further develop services on July 1, 2009 [21].

\section{Case 2. Centrelink}

Centrelink is a general civil application center related to manpower services that provides various services ranging from educational labor-management relations to family residence communities for natives and creative industry and science research [20]. It serves approximately 6.5 million clients every year with 140 or so civil services that had previously been performed by 10 federal departments and 25 government agencies, 
including job placement, assistance with creating independent businesses, approving unemployment and providing unemployment benefits, preparing written employment activity plans, vocational training, nursing, assistance with divorces or separation by death, farming and watering, immigration, disease, injury and disability, old age, funerals, and other aspects of daily life.

Job seekers consult with case managers and complete and sign employment preparation agreements when they apply for income support programs such as unemployment benefits. The case managers check regularly to see whether applicants have been performing their assigned duties such as job hunting and vocational training. Here, a mutual obligation is reinforced in that the job seekers themselves must make active efforts to pursue employment.

\section{Directions for Developing Employment Centers and Duties in Korea}

\subsection{Task 1: Expand (Quantitative) and Enhance (Qualitative) the Public Employee Service Including the Employment Centers}

Following are the necessary tasks and development scheme based on the current employment center issues. First, there is a need to expand and enhance current public employment services, including connecting services for each department and each business, strengthening the reconciliation, and advancing the centers' core functions. This will require structuring the governance so as to evaluate and adjust the employment service delivery for each department and, ultimately, each metropolitan region so that all can perform comprehensive employment service functions and operate the centers as base units that will be tentatively called individual units of Central Employment Service Commission. Germany, for instance, has established the Bundesagentur fur Arbeit (BA) to perform the central duties of an employment service delivery system. The BA is the main body for executing aggressive labor market policies, brokering employment, providing employment insurance and unemployment benefits, and so forth [22].

\subsection{Task 2: Revise the Public Employee Service Agencies around the Employment Centers to Strengthen them}

The private consignment of the public employment service requires waiving the public monopoly while revising the public employee service agencies that are affiliated with the employment centers in order to realign the public services as valuable public goods. For example, employment centers may need to adjust their main roles by providing appropriate specific services, including expanded outreach to the vulnerable classes, enhancing construction and foreign human resources, and so forth. In addition, three plans are presented for enhancing the efficiency of private employee service agencies while maintaining the quasi-market nature of public employee service: 1) enlarge the private employee service agencies and share roles with the employment centers by adjusting the business territories; 2) strengthen support for standardizing services and promote public service by facilitating management, certifications, and incentives, through developing quasi-public private employee service agencies, and 3) develop integrated HR service agencies by reforming private employee service agency regulations [23].

\subsection{Task 3: Manage Personnel and Offer Education on the Employment Centers}

Third, it will be necessary to better manage personnel, partly by offering education on the centers, in order to further specialize human resources and enhance institutional competence by expanding infrastructure investments in the centers. The current situation requires budgets and plans for increasing the number of employees each year as well as requests to increase human resources by expanding welfare and establishing more employment centers. Additionally, Task 3 would require reviewing the current reductions 
in administrative human resources who work at the centers, controlling individual centers' transfer arrangements by establishing new centers, and reviewing staffing to maintain specialization. It is also necessary to establish employee competence training for the center employees through employment and labor training as well as by providing employees the opportunity to improve their specialization by taking required credits.

\subsection{Task 4: Improve Human Resource Specialization and Employment Service Methods}

Fourth, it will be necessary to improve human resource specialization and employment service methods to appropriately reflect current innovations in information and technology. Through the employment information network, advanced examinations, the desire for work, job seekers are surveyed before they visit the employment centers. Thus, interview times can be shortened, and advanced support can be provided through tailored information. The information provision method needs to be modified in order to be able to provide high-quality employment information based on big data. Furthermore, job seekers' online consultations should be facilitated as they prepare their job search plans in order to provide them with appropriate information on enterprises, wages, etc., which will increase the efficiency of employment service.

\section{Conclusion}

This study suggests policy insights to contribute to promoting employment for a wide variety of job seekers (youth, women, the disabled and aged, etc.,) in Korea. Four necessary improvements are highlighted for expanding the functions of both public and private employment services and for effectively executing government policies.

First, it is necessary to expand private employment services and introduce competition to improve the quality of these services. Currently, Korea's public employment services are a system for wage earners based on employment insurance with private employment services such as a job placement, subcontracting, and outsourcing services for low-income workers. Overseas cases reveal that recently and generally, public employment services eventually make way for private ones, which have been expanded and developed. States such as Australia, America, and England use private agencies relatively actively and see the trend of their markets being expanded continuously. Therefore, we expect to introduce a performance assessment system such as the star ratings in Australia, where the number of successful job placements by agencies is counted for professions for the long-term unemployed to move up from unemployment. In addition, it is necessary to make up for the functions of our general employment services by benchmarking employment service reform through private and public consortia.

Second, connections between employment and welfare and one-stop service centers are required. Namely, services for employment, vocational training, welfare, and others should be connected each other to provide them as a combined employment service package in order to ensure employment services that are customized for individuals. A system such as the one-stop centers in America and Centrelink in Australia is badly needed for anyone who seeks work and wishes to take advantage of combined services. Because a service system through which multiple governmental agencies provide services through different front-line channels in different ways not only brings about inconvenience for both would-be employers and employees but also severely limits the cost efficiency of employment services, it is necessary to aim at convenience and administrative unity for both parties with one-stop service that can handle unemployment benefits, employment matters, vocational training, and welfare in generally.

Third, the government must allocate budgets for long-term employment services to meet the global economic crises [24]. Advanced countries with more serious employment problems than Korea allocate much more of their budgets for employment services 
(average $26 \%$ in the OECD, 2010). It is now that Korea, with a $2.7 \%$ budget allocation, must prepare for the future. In this case, we could build a systematic employment service infrastructure, train professional personnel to operate it, and focus on the vulnerable groups such as the long-term unemployed.

Fourth, it is also critical that we find methods to build up service channels to provide appropriate workers for medium and small-sized enterprises as we expand and develop the employment centers further. It has also been observed that global capabilities should be reinforced to respond to the transfer of global manpower, identifying and supplying capable persons at both the local and national levels. Additionally, the establishment of public temporary agencies must be considered for social services first.

\section{References}

[1] Y. S. Choi, J. Y. Hong and S. W. Hong, "Market premium to meeting or beating earnings expectations during the economic crisis: evidence from Korea", Advanced Science Technology Letters, vol. 47, (2014), pp. 113-116.

[2] E. Clarence and M. Peromingo, "Long-term unemployment", ILO Employment Outlook, (2013).

[3] S. T. Kim, "Tasks of advancement for employment service and development of specialized human resources", International Labor Brief, (2014) October, pp.1-3.

[4] S. T. Kim, "Prospect and major policies for labor market of each country in 2015", International Labor Brief, (2015) February, pp. 1-3.

[5] "World Association of Public Employment Services", Retrieved from http: www. http://wapes.org.

[6] S. H. Choi and S. W. Oh, "Empirical study on determinant factor of efficiency for employment service institution of Korea by using the envelopment model: centered around work structure, finance, employment outcome of employment center", Korea Policy Academy Newsletter, vol. 20, no. 4, (2011), pp. 479-503.

[7] S. W. Oh, "Scheme of development to structure outcome management system of public employment service", Study on Occupation and Employment Service, vol. 7, no. 2, (2012), pp. 17-33.

[8] U. S. Jang, "Status and development scheme of public employment service", Overview of Researches, vol. 2010, no. 1, (2010), pp. 8-31.

[9] R. J. Torraco, "Writing integrative literature reviews: guidelines and examples", Human Resources Development Review, vol. 4, no. 3, (2005), pp. 356-367.

[10] "Korea Law Information Center", Retrieved from http: www.law.go.kr.main.html.

[11] "Ministry of Employment and Labor", Retrieved from http: www.moel.go.kr.

[12] "Ministry of Employment and Labor", Employment Service Policy Dept., (2015).

[13] Y. S. Joo, I. H. Park, J. Y. Park and H. A. Kim, "Study on situation of non-government employees employed by employment centers and ways of combining jobs", Ministry of Employment and Labor (2014.9).

[14] "Revision of Operation Regulations for Employment Centers and Employment Agencies (Execution", Inst. 2015. 1. 30), Ministry of Employment and Labor, (2015).

[15] J. S. Park, W. K. Hong and G. S. Jo, "Study on legislation for development of employment services", Ministry of Employment and Labor, (2013. 12).

[16] M. G. Clagett, "Workforce development in the Unites State: an overview", National Center on Education and the Economy, (2006).

[17] General Accounting Office (GAO), "Workforce Training: almost half of states fund employment placement and training through employer taxes and most coordinate with federally funded programs (GAO-04-282)", Washington, D.C.: U.S. Government Printing Office, (2004).

[18] General Accounting Office (GAO), "Workforce investment act: one-stop system infrastructure continues to evolve, but labor should take action to require that all employment service offices are part of the system", GAO-07-1096, Washington, D.C.: U.S. Government Printing Office, (2007b).

[19] E. Kairouz, "Employment security service of Australia: job network", International Labor Brief, Korea Labor Institute, vol. 2, no. 2, (2004), pp. 57-63.

[20] "OECD", Activating Jobseekers: How Australia Does It, (2012).

[21] D. Finn, "Job services Australia: design and implementation lessons for the British context", Department for Work and Pensions Research Report, no. 752, (2011).

[22] M. J. Park, "Employment Service of Germany: Delivery System and Provision Method of Public Service", International Labor Brief, (2013) October, pp. 17-29.

[23] Y. M. Lee and J. H. Oh, "Implication on policy for revising public employment service in Korea: focused on the employment center", Proceeding of Advanced Science and Technology Letters, vol. 102 (2015), pp. 38-42.

[24] J. Kim, "A senior-citizen status and the government's welfare budget, the stabilization of the alternatives", Advanced Science and Technology Letters, vol. 95 (2015), pp. 153-158. 


\section{Authors}

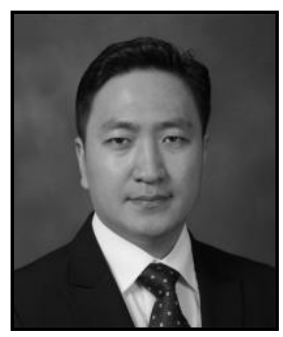

Young-Min Lee, Ph.D., is an associate professor of graduate school of human resources development for women and the director of industry and academic cooperation center at Sookmyung Women's University. His main research areas include human resource development, workforce development and management of aging workforce.

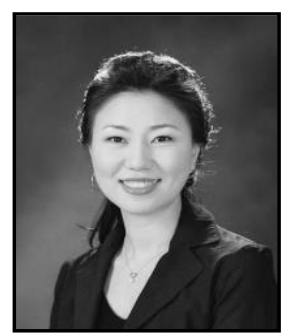

Ji-Hyun Oh, $A B D$, is an adjunct professor of department of secretarial office administration at Baewha Women's University and training director of Korean Association of Administrative Professionals. Her main research areas include employment service, extension of retirement of age and human resources management. 